\title{
IMPROVEMENT OF VOLYBALL LOWER PASSING SKILLS THROUGH JIGSAW LEARNING MODEL IN CLASS IX-J STUDENTS OF MTSN 4 JOMBANG
}

\section{PENINGKATAN KETERAMPILAN PASSING BAWAH BOLA VOLI MELALUI MODEL PEMBELAJARAN JIGSAW PADA SISWI KELAS IX-J MTSN 4 JOMBANG}

\author{
Umarul Faruk \\ M TSN 4 Jombang \\ E-mail : faruqmoh@gmail.com \\ DOI: https://doi.org/10.52048/inovasi.v15i1.238
}

\begin{abstract}
This study aims to improve the voliball game skills of class IX-J MTsN 4 Jombang students in the 2019/2020 school year. The subjects of this study were students of class IX-J MTsN 4 Jombang in the 2019/2020 school year. This type of research is classroom action research. Three cycles of this research instrument consist of learning observation sheets and student test sheets. The data from this study were analyzed using the formula for the average percentage score of the results of the research instrument. The results of this study indicate that there is an increase in the average value of student learning outcomes from each research cycle, with details of the average score in the first cycle $(73.33 \%)$, the second cycle $(86.66 \%)$, and the third cycle $(96.66 \%)$. The conclusion of this study is that the jigsaw learning model has the potential to improve the mastery of voliball underpassing skills for class IX-J MTsN 4 Jombang students in the $2019 / 2020$ school year.
\end{abstract}

Keywords: Jigsaw, Passing down, Voliball.

\section{ABSTRAK}

Penelitian ini bertujuan untuk meningkatkan Keterampilan permainan bola voli siswi kelas IX-J MTsN 4 Jombang tahun pelajaran 2019/2020. Subjek penelitian ini adalah siswi kelas IX-J MTsN 4 Jombang tahun pelajaran 2019/2020. Jenis penelitian ini adalah Penelitian tindakan kelas Dilakukan tiga siklus Instrumen penelitian ini terdiri dari Lembar observasi pembelajaran dan lembar tes siswa. Data hasil penelitian ini dianalisis dengan menggunakan rumus persentase rerata skor hasil instrumen penelitian. Hasil penelitian ini menunjukkan bahwa terdapat peningkatan rerata nilai hasil belajar siswi dari setiap siklus penelitian, dengan rincian rerata skor pada siklus I sebesar $(73,33 \%)$, siklus II $(86,66 \%)$, dan siklus III $(96,66 \%)$. Kesimpulan penelitian ini adalah model pembelajaran jigsaw berpotensi meningkatkan penguasaan Keterampilan passing bawah bola voli siswi kelas IX-J MTsN 4 Jombang tahun pelajaran 2019/2020.

Kata Kunci: Jigsaw, Pasing bawah, Bola Voli

\section{PENDAHULUAN}

\section{A. Latar Belakang}

Pendidikan jasmani, Olahraga dan kesehatan merupakan proses pendidikan yang memanfaatkan aktivitas jasmani dan membiasakan pola hidup sehat dalam kehidupan seharihari. Hal ini mempunyai peran penting dalam membina serta mengembangkan individu maupun kelompok untuk menunjang pertumbuhan dan perkembangan jasmani, mental sosial, serta emosional yang serasi, selaras dan seimbang. Permainan bola voli adalah permainan yang dapat dimainkan di dalam maupun di luar ruangan dengan sangat leluasa. Dan menurut penjelasannya pada saat itu, permainan ini dapat juga dimainkan kurang 6 
pemain. Tidak ada batasan jumlah pemain yang menjadi standar dalam permainan tersebut. Sedangkan sasaran dari permainan ini adalah mempertahankan bola agar tetap bergerak melewati net yang tinggi, dari satu wilayah ke wilayah lain (wilayah lawan).

Menurut pendapat Mashar \& Dwinarhayu (2010: 5) "Permainan bolavoli merupakan permainan yang dimainkan secara beregu. Tiaptiap regu terdiri dari 6 pemain". Permainan bola voli merupakan permainan tim maka seseorang pemain harus punya ketrampilan individu yang baik. Setiap pemain mempuyai teknik, servis (pukulan pertama dalam permainan). Passing bawah/ passing atas (pukulan/pengambilan bola yang di berikan ke tosser). Smash (serangan pukulan yang keras waktu bola berada di atas jaring, untuk dimasukan ke daerah lawan). Blocking (menahan/ menghalangi bola yang datang dari daerah lawan). Passing adalah upaya seseorang pemain dengan menggunakan teknik tertentu untuk mengoperkan bola kepada teman seregunya. Dalam permainan bola voli kita akan mengenal 2 macam passing (mengoper) bola yaitu mengoper (passing) bola dengan tangan dari bawah (kedua tangan dirapatkan) atau passing bawah dan mengoper (passing) bola degan tangan di atas (menggunakan jari-jari tangan atau passing atas). Menurut Sarjiyanto \& Sujarwadi (2010:6) "Yang dimaksud passing bawah adalah pengambilan bola dengan tangan bergandengan satu sama lain dengan ayunan dari bawah atas depan".

Selain digunakan untuk mengoper bola passing bawah juga dapat digunakan ketika menerima bola, serta mengambil bola yang datangnya dari bawah adapun latihan teknik dasar passing bawah antara lain. Sikap satu kaki maju, kedua lutut di tekuk, badan sedikit dibengkokkan ke depan, kedua tangan berpegangan dengan cara punggung kanan diletakkan tangan kiri jari digengam erat. Gerakan passing bawah normal ayunan kedua tangan kearah bola dengan sumbu gerak pada persendian bahu, dan siku di dalam keadaan betul-betul lurus.

Keterampilan Passing bawah bola voli siswi dapat dikembangkan melalui aktivitas pembelajaran yang dikendalikan oleh guru melalui model dan metode pembelajaran. Model pembelajaran yang dapat melatihkan keterampilan Passing bawah bola voli siswi antara lain model pembelajaran jigsaw Vanalita, Jalmo, \& Marpaung,(2014: 3). Jigsaw mampu meningkatkan keterampilan Passing bawah bola voli siswi melalui diskusi kelompok ahli dan kelompok asal yang dapat meningkatkan pemahaman siswi terhadap materi. Jigsaw melibatkan siswa untuk berinteraksi satu sama lain melalui kelompok ahli dan kelompok asal sehingga siswa terbiasa untuk aktif.

Banyak dari siswa-siswi MTsN 4 Jombang dalam pembelajaran permainan bola voli hanya mengandalkan smash padahal dalam permainan bola voli perlu di perhatikan adalah servis, passing, smash, dan blocking. Kalau dari ke 4 unsur itu tercapai maka permainan bola voli bisa berkembang baik dan enak dilihat oleh semua orang. Oleh karena itu perlu sebuah pemecahan masalah yang sederhana dan bisa dilakukan oleh guru. Untuk mendapatkan hasil belajar keterampil passing bawah pada bola voli yang maksimal dari peserta didik, guru perlu berinovasi mencari model pembelajaran yang sesuai dengan karakteristik peserta didik dan materi yang kita akan sampaikan.

Berdasarkan kondisi pada Siswi MTsN 4 Jombang kelas IX-J yang berjumlah 30 siswi putri tersebut maka untuk membantu guru dalam mengajarkan keterampilan passing bawah bola voli maka peneliti melakukan inovasi kegiatan belajar mengajar dengan menerapkan model pembelajaran jigsaw terhadap penguasaan keterampilan passing bawah bola voli siswi kelas IX-J MTsN 4 Jombang.

\section{B. Rumusan Masalah}

Berdasarkan latar belakang di atas maka permasalahan yang perlu dikaji dalam penelitian ini adalah :

1. Bagaimanakah proses penerapan pembelajaran jigsaw terhadap penguasaan keterampilan passing bawah Bola Voli siswi kelas IX-J MTsN 4 Jombang ?

2. Apakah model jigsaw dapat meningkatkan hasil belajar peserta didik pada keterampilan 
passing bawah bola voli ?

\section{Tujuan Penelitian}

Adapun tujuan dari penelitian ini adalah

1. Untuk Mengetahui proses penerapan pembelajaran jigsaw terhadap penguasaan Keterampilan passing bawah Bola Voli siswi kelas IX-J MTsN 4 Jombang.

2. Untuk Mengetahui hasil belajar siswi kelas IX-J MTsN 4 Jombang setelah belajar Keterampilan passing bawah bola voli menggunakan model jigsaw.

\section{KAJ IAN TEORI}

\section{A. Hakikat Permainan bola voli}

Permainan bola voli adalah cabang olahraga beregu yang dimainkan oleh dua tim, masingmasing tim terdiri dari 6 orang yang dipisahkan oleh jaring/net. Masing-masing tim berhak memainkan bola sampai tiga kali sentuhan, untuk mengembalikan ke daerah lawan. Seorang pemain tidak diperbolehkan memainkan bola dua kali berturut-turut. Agar dapat bermain bola voli dengan baik seseorang harus mengerti dan dapat menguasai teknik )teknik dasar yang ada. Yang dimaksud teknik dalam pembahasan ini menurut Suharno HP. (1993 : 12) "suatu proses melahirkan keaktifan jasmani dan pembuktian suatu praktek dengan sebaik mungkin untuk menyelesaikan tugas yang pasti dalam cabang permainan bolavoli”. Menurut Suharno HP. (1993: 11) mengatakan bahwa unsur-unsur gerak yang perlu dijaga agar tetap dalam kondisi puncak adalah: 1] Daya ledak (power) berguna untuk meloncat dan mencambuk bola dalam smash dan block. 2] Kecepatan beraksi berguna untuk kecepatan reaksi gerakan setelah ada rangsang bola dari lawan. 3] Stamina, kemampuan daya tahan tinggi untuk menjalankan permainan bola voli dengan tempo tinggi, frekuensi tinggi, tenaga tinggi, dan produktif dalam waktu tertentu. 4] Kelincahan untuk merubah arah dalam pengambilan posisi badan saat bermain. 5] Kelentukan sendi-sendi, agar kelihatan luwes sehingga muncul seni gerak dalam bermain bola voli. Nuril Ahmadi (2007 : 19) mengatakan, Permainan bolavoli merupakan suatu permainan yang komplek yang tidak mudah untuk dilakukan oleh setiap orang. Diperlukan pengetahuan tentang teknik-teknik dasar dan teknik-teknik lanjutan untuk dapat bermain bolavoli secara efektif. Teknik-teknik tersebut meliputi: service, passing, smash, dan sebagainya. Menurut Sukintaka dkk. (1979 : 17), "Permainan bola voli adalah suatu cabang olahraga berbentuk memvoli bola diudara, hilir mudik diatas jaring/net dengan maksud dapat menjatuhkan bola didalam petak lapangan lawan untuk mencari kemenangan dalam bermain". Pendapat senada dikemukakan juga oleh M. Yunus (1992 : 69) yang mengatakan bahwa bolavoli merupakan permainan yang dimainkan dalam 6 bentuk kerja sama tim dan dibatasi net. Setiap tim berusaha untuk melewatkan bola secepat mungkin ke daerah lawan dengan menggunakan teknik dan taktik yang sah. A. Sarumpaet dkk. (1992: 78) mengatakan, Permainan bolavoli merupakan salah satu cabang olahraga permainan besar yang dimainkan oleh dua regu yang masingmasing regu terdiri dari 6 orang pemain. Dasar permainan bola voli ialah memainkan bola dengan memvoli dan berusaha menjatuhkan bola di dalam lapangan permainan lawan dengan menyeberangkan bola lewat atas net/jaring, dan mempertahankannya supaya tidak jatuh di lapangan sendiri.

\section{B. Teknik Dasar Passing:}

Teknik Dasar Passing 1] Passing bawah Aip Syarifuddin (1991 : 189) mengatakan, Pass (passing) bawah adalah mengambil bola yang berada di bawah badan atau bola dari bawah dan biasanya dilakukan dengan kedua lengan bagian bawah (dari siku sampai pergelangan tangan yang dirapatkan), baik untuk dioperkan kepada kawan, maupun langsung ke lapangan lawan melalui di atas jaring. Menurut Sugiarto (2009 : 21), "Hal yang perlu kamu perhatikan dalam passing bawah adalah gerakan mengambil bola, mengatur pisisi, memukul bola dan mengarahkan bola ke arah sasaran". Nuril Ahmadi (2007 : 23) mengatakan bahwa kegunaan passing bawah antara lain: 1] Untuk menerima bola servis. 2] Untuk penerimaan bola dari lawan 
yang berupa serangan/ smash. 3] Untuk pengambilan bola setelah terjadi block atau bola dari pantulan net. 4] Untuk menyelamatkan bola yang kadang-kadang terpental jauh di luar lapangan permainan. 5] Untuk pengambilan bola yang rendah dan mendadak datangnya. Sukintaka, dkk. (1979 : 31) mengatakan, Teknik pass bawah itu sikap permulaan: ambil posisi sikap siap normal. Pada saat tangan akan dikenakan pada bola, segera tangan dan juga lengan diturunkan serta, tangan dan lengan dalam keadaan terjulur ke bawah depan lurus. Siku tidak boleh ditekuk, kedua lengan merupakan papan pemukul yang selalu lurus keadaannya.

\section{Model Pembelajaran}

Model pembelajaran adalah suatu perencanaan atau suatu pola yang digunakan sebagai pedoman dalam merencanakan pembelajaran di kelas atau pembelajaran tutorial dan untuk menentukan perangkat pembelajaran termasuk di dalamnya buku-buku, film, komputer, kurikulum dan lain-lain (Trianto, 2007 : 5). Sebelum menentukan model pembelajaran yang akan di gunakan dalam kegiatan pembelajaran, ada beberapa hal yang harus dipertimbangkan guru dalam memilihnya (Rusman, 2011 : 133) yaitu:

a. Pertimbangan terhadap tujuan yang hendak dicapai.

b. Pertimbangan yang berhubungan dengan bahan atau materi pembelajaran.

c. Pertimbangan dari sudut peserta didik atau siswa.

d. Pertimbangan lainnya yang bersifat non teknis.

Ada beberapa model diskusi kelompok berbasis pembelajaran kooperatif (Depdiknas, 2005 : 41-42), antara lain sebagai berikt:

1. Student Teams-Achievement Divisions (STAD) yang menggunakan langkah pembelajaran di kelas dengan menempatkan peserta didik ke dalam tim campuran berdasarkan prestasi, jenis kelamin, dan suku.

2. Team-Assisted Individualization (TAI) yang lebih menekankan pengajaran individual meskipun tetap menggunakan pola kooperatif.

3. Cooperative Integrated Reading and Composition $(\mathrm{ClRC})$ yang digunakan untuk pembelajaran membaca dan menulis tingkat tinggi.

4. Jigsaw yang mengelompokkan peserta didik ke dalam tim beranggotakan lima sampai enam orang yang memelajari materi akademik yang telah dibagi-bagi menjadi beberapa sub bab.

5. Learning Together (belajar bersama) yang melibatkan peserta didik untuk bekerja dalam kelompok beranggotakan empat atau lima peserta didik heterogen untuk menangani tugas tertentu.

6. Group Investigation (penelitian kelompok) berupa pembelajaran kooperatif yang bercirikan penemuan.

\section{Pengertian Model Pembelajaran Jigsaw}

Model pembelajaran jigsaw adalah suatu teknik pembelajaran kooperatif yang terdiri dari beberapa anggota dalam satu kelompok yang bertanggung jawab atas penguasaan bagian materi tersebut kepada anggota lain dalam kelompoknya.

Menurut Fathurrohman (2015: 63). Model Pembelajaran kooperatif jigsaw membagi peserta didik menjadi beberapa kelompok. Setiap kelompok memiliki seorang ahli yang diharuskan untuk menguasai salah satu bagian dari materi yang dipelajari. Selanjutnya semua ahli dari masing-masing kelompok bersatu membentuk kelompok ahli untuk mempelajari dan mendiskusikan bagian materi yang harus mereka kuasai. Setelah itu semua anggota kelompok ahli kembali ke kelompok asal masing-masing dan membagikan hasil disksinya.

Menurut Rusman (2018 : 217) kata jigsaw berasal dari bahasa Inggris yang berarti gergaji ukir dan ada juga yang mengartikannya sebagai puzzle yang berarti sebuah teka-teki menyusun potongan gambar. Pembelajaran kooperatif tipe jigsaw ini mengambil pola cara bekerja gergaji (Zigzag), yaitu siswa melakukan suatu kegiatan belajar dengan cara bekerja sama antar kelompok dengan silangan siswa kelompok lain (kelompok ahli) untuk mencapai tujuan bersama.

Berdasarkan pemaparan di atas, tidak heran rasanya jika Isjoni (2013: 77) ber- 
pendapat bahwa model pembelajaran kooperatif tipe jigsaw merupakan salah satu tipe model pembelajaran kooperatif yang mendorong siswa aktif dan saling membantu dalam menguasai materi pembelajaran untuk mencapai prestasi yang maksimal.

Jigsaw merupakan salah satu tipe, jenis, atau turunan dari model pembelajaran kooperatif yang mengutamakan kerja sama peserta didik dalam prosesnya. Namun, sentuhan zig-zag yang diberikan jigsaw boleh dikatakan makin memperuncing kerja sama yang terjadi. Sehingga peserta benar-benar harus mampu bertanggung jawab kepada diri sendiri dan banyak rekanrekannya yang lain dalam sekali kayuh.

Model pembelajaran jigsaw menurut para ahli Juga memiliki pandangan dan pendapatnya masing-masing mengenai salah satu model pembelajaran yang paling inovatif dan kompleks. Berikut adalah pendapat-pendapat tersebut.

Menurut Istarani (2014: 81) Model pembelajaran tipe jigsaw adalah model yang dirancang untuk meningkatkan rasa tanggung jawab siswa terhadap pembelajarannya sendiri dan juga pembelajaran orang lain. Siswa tidak hanya mempelajari materi yang diberikan, tetapi mereka juga harus siap memberikan dan mengajarkan materi tersebut kepada kelompoknya sehingga kemampuan secara kognitif maupun sosial meningkat.

Menurut Lie (dalam Majid, 2017 : 182) Pembelajaran kooperatif model jigsaw merupakan model pembelajar kooperatif dengan cara siswa belajar dalam kelompok kecil yang terdiri atas empat sampai dengan enam orang secara heterogen, dan siswa bekerjasama dalam lingkup saling ketergantungan positif sekaligus bertanggung jawab secara mandiri.

Suherti dan Maryam (2016 : 93) berpendapat, "Model pembelajaran Jigsaw merupakan model pembelajaran kooperatif yang berpusat pada peserta didik, sedangkan guru bertindak hanya sebagai fasilitator dan motivator serta menitikberatkan pada kerja kelompok dalam kelompok kecil".

Menurut Majid (2017 : 182) model pembelajaran jigsaw adalah sebuah varian model pembelajaran kooperatif yang menitikberatkan pada kerja kelompok siswa dalam bentuk kelompok kecil.

Kunci tipe Jigsaw ini adalah interdependence setiap siswa terhadap anggota tim yang memberikan informasi yang diperlukan. Artinya para siswa harus memiliki tanggung jawab dan kerja sama yang positif dan saling ketergantungan untuk mendapatkan informasi dan memecahkan masalah yang diberikan.

\section{E. Langkah-Langkah Model Pembelajaran Jigsaw}

Langkah-langkah kegiatan pembelajaran dengan Model Pembelajaran tipe Jigsaw adalah sebagai berikut:

a. Membentuk kelompok heterogen yang beranggotakan 4 - 6 orang

b. Tiap orang dalam kelompok diberi sub topik yang berbeda.

c. Setiap kelompok membaca dan mendiskusikan sub topik masing-masing dan menetapkan anggota ahli yang akan bergabung dalam kelompok ahli.

d. Anggota ahli dari masing-masing kelompok berkumpul dan mengintegrasikan semua sub topik yang telah dibagikan sesuai dengan banyaknya kelompok.

e. Kelompok ahli berdiskusi untuk membahas topik yang diberikan dan saling membantu untuk menguasai topik tersebut.

f. Setelah memahami materi, kelompok ahli menyebar dan kembali ke kelompok masingmasing, kemudian menjelaskan materi kepada rekan kelompoknya.

g. Tiap kelompok memperesentasikan hasil diskusi.

h. Guru memberikan tes individual pada akhir pembelajaran tentang materi yang telah didiskusikan.

i. Siswa mengerjakan tes individual atau kelompok yang mencakup semua topik.

\section{F. Kelebihan Model Pembelajaran Jigsaw}

Bila dibandingkan dengan model pembelajaran tradisional, model pembelajaran Jigsaw memiliki beberapa kelebihan yaitu: 
a. Mempermudah pekerjaan guru dalam mengajar, karena sudah ada kelompok ahli yang bertugas menjelaskan materi kepada rekan-rekannya.

b. Pemerataan penguasaan materi dapat dicapai dalam waktu yang lebih singkat

c. Model pembelajaran ini dapat melatih siswa untuk lebih aktif dalam berbicara dan berpendapat.

Diskusi dalam kelompok ini, untuk mengatasi masalah atau kelemahan yang muncul dalam penerapan model pembelajaran kooperatif tipe jigsaw, dapat dilakukan dengan cara sebagai berikut:

a. Pengelompokan dilakukan terlebih dahulu, meng urutkan kemampuan belajar siswa dalam kelas.

b. Sebelum tim ahli, misalnya ahli materi pertama kembali ke kelompok asal yang akan bertugas sebagai tutor sebaya, perlu dilakukan tes penguasaan materi yang menjadi tugas mereka

Dalam penerapannya sering dijumpai beberapa permasalahan, yaitu :

a. Siswa yang aktif akan lebih mendominasi diskusi, dan cenderung mengontrol jalannya diskusi.

b. Siswa yang memiliki kemampuan membaca dan berpikir rendah akan mengalami kesulitan untuk menjelaskan materi apabila ditunjuk sebagai tenaga ahli.

c. Siswa yang cerdas cenderung merasa bosan.

d. Pembagian kelompok yang tidak heterogen, dimungkinkan kelompok yang anggotanya lemah semua.

e. Penugasan anggota kelompok untuk menjadi tim ahli sering tidak sesuai antara kemampuan dengan kompetensi yang harus dipelajari.

f. Siswa yang tidak terbiasa berkompetisi akan kesulitan untuk mengikuti proses pembelajaran.

\section{G. Tujuan Model J igsaw}

Tujuan pembelajaran model jigsaw adalah untuk melatih peserta didik agar terbiasa berdiskusi dan bertanggiung jawab secara individu untuk membantu memahamkan tentang sesuatu materi pokok kepada teman sekelasnya. Pembelajaran yang menggunakan model ini menganut pada teori kognitif Jean Piaget dan teori konstruktivisme.
Teori konstruktivisme didefinisikan sebagai pembelajaran yang bersifat generatif, yaitu tindakan mencipta sesuatu makna dari apa yang dipelajari. Konstruktivisme sebenarnya bukan merupakan gagasan yang baru, apa yang dilalui dalam kehidupan kita selama ini merupakan himpunan dan pembinaan pengalaman demi pengalaman. Pembinaan pengetahuan seperti ini menyebabkan seseorang mempunyai pengetahuan dan menjadi lebih dinamis.

\section{METODE PENELITIAN}

Wijaya Kusumah dan Dedi Dwitagama (2011 : 9) menyatakan penelitian tindakan kelas adalah penelitian tindakan (action research) yang dilakukan oleh guru di dalam kelas dan memiliki rangkaian "riset-tindakanriset-tindakan-riset tindakan...", yang dilakukan dalam rangkaian untuk memecahkan masalah. Penelitian Tindakan Kelas ini berbentuk kolaborasi yaitu menjalin kemitraan dan bekerjasama dengan guru bertujuan memperoleh informasi - informasi mengenai pembelajaran. Dengan demikian permasalahan pembelajaran di kelas dapat teratasi bersama, sehingga kualitas pembelajaran dapat ditingkatkan.

Penelitian Tindakan Kelas(PTK) terhadap penguasaan keterampilan passing bawah bola voli ini menggunakan kaidah-kaidah prosedur penelitian tindakan kelas (PTK). Sejalan dengan realitas bahwa guru sebagai lembaga profesi untuk selalu mengikuti perkembangan zaman. Seorang guru tidak hanya memiliki kemampuan teknis edukatif saja tetapi harus memiliki keterampilan yang dapat diandalkan sehingga berdampak langsung pada perilaku Siswa-siswi di madrasah dan tindakannya dalam mengikuti kegiatan belajar mengajar (KBM) bidang studi penjaskes.

\section{A. Rancangan Penelitian}

Penelitian tindakan kelas (PTK) ini dilaksanakan di MTsN 4 Jombang yang terletak di jalan KH Bishri Syansuri 77 Denanyar Jombang. Penelitian ini diterapkan pada mata pelajaran Pendidikan jasmani olahraga dan kesehatan. Sebagai subyek dalam penelitian ini adalah 
siswi kelas IX-J tahun pelajaran 2019/2020 dengan jumlah siswi 30 orang.

Penelitian tindakan kelas (PTK) ini di laksanakan selama 2 bulan dari bulan Oktober sampai Nopember 2019. Pertemuan waktu penelitian mengacu pada kalender pendidikan Madrasah, karena penelitian tindakan kelas (PTK) ini memerlukan beberapa siklus yang membutuhkan proses belajar mengajar yang efektif di kelas, yaitu pada hari Rabu jam 08.10 sd 09.30 WIB (jam ke 3 dan 4)

\section{B. Jadwal Penelitian}

\begin{tabular}{|l|l|l|}
\hline No. & \multicolumn{1}{|c|}{ Tanggal } & \multicolumn{1}{|c|}{ kegiatan } \\
\hline 1. & 09 Oktober 2019 & Repleksi awal \\
2. & 16 Oktober 2019 & Siklus I \\
3. & 30 Oktober 2019 & Siklus II \\
4. & 13 Nopember 2019 & Siklus III \\
\hline
\end{tabular}

\section{Metode Pengumpulan Data}

Data-data yang diperlukan dalam penelitian ini diperoleh melalui observasi pengolahan belajar aktif, observasi aktivitas siswi dan guru, dan tes keterampilan pasing bawah bola voli.

Data aktivitas siswi dikumpulkan dalam bentuk angka, sedangkan observasi aktivitas guru berupa data deskripsi saja.

\section{Prosedur Penelitian}

Penelitian ini dilaksanakan dalam 3 siklus, masing-masing siklus terdiri dari 4 tahap yaitu :

1. Perencanaan Tindakan (Planning)

2. Pelaksanaan Tindakan (Action)

3. Observasi (Observation)

4. Refleksi (Reflection)

\section{TEMUAN DAN PEMBAHASAN}

\section{A. Temuan}

Pembelajaran keterampilan passing bawah bola voli dengan model pembelajaran Jigsaw dilaksanakan dengan cara:

1. Membagi menjadi 6 kelompok satu kelompok beranggota 5 siswi.

2. Setiap anggota bertanggung jawab untuk mempelajari bagian tertentu dari bahan yang diberikan.

3. Anggota dari kelompok lain yang mendapat tugas topik yang sama berkumpul dan berdiskusi dengan topik tersebut. Kelompok ini disebut kelompok ahli.

4. Kemudian tim ahli ini kembali ke kelompok asal dan mengajarkan apa yang telah dipelajari dan didiskusikan dalam kelompok ahlinya untuk diajarkan kepada teman kelompok sendiri.

Guru Menyampaikan tujuan pembelajar yaitu

1. Siswi mampu melakukan, mendeskripsikan dan mengutarakan kembali pengalaman pribadi dan temannya tentang passing bawah

2. Siswi mampu memberikan tanggapan, mengaju kan pertanyaan dan saran disertai alasan yang logis terhadap tema ketrampilan passing bawah.

Guru menyampaikan tema pembelajaran passing bawah kepada siswi. Guru membantu siswi mengatur posisi tangan dan kaki pada saat passing bawah. Guru membagikan tema kepada setiap kelompok dan memintak siswi mendiskusikan tema tersebut. Guru membimbing siswi melakukan ketrapilan passing bawah. Kemudian siswi yang mendapat tugas yang sama berkumpul dan berdiskusi dengan topik tersebut, kelompok ini disebut kelompok ahli passing bawah, Guru menggali pendapat siswi dengan cara siswi diminta melakukan passing bawah yang pernah dilihat sendiri. Guru memberi kesempatan kepada siswi untuk saling membantu dan memdiskusikan. Kemudian kelompok ahli ini kembali ke kelompok asal dan mengajarkan apa yang telah dipelajari dan didiskusikan dalam kelompok ahlinya untuk diajarkan kepada teman kelompok sendiri. Guru memberi kesempatan kepada siswi dari kelompok lain untuk memberi tanggapan atau mengajukan pertanyaan yang berkaitan dengan peristiwa tersebut.

Berdasarkan penelitian yang telah dilakukan melalui penerapan model pembelajaran jigsaw, secara empiris diperoleh data peningkatan prestasi belajar penjaskes dalam keterampilan passing bawah bola voli.

Pada saat melakukan pre test, siswi banyak melakukan kesalahan, diantaranya sikap awalan, sikap pelaksanaan dan akhir gerakan yang tidak sempurna. Pencapaian hasilnya pun kurang maksimal keseluruhan testee hanya bisa mencapai 
nilai tertinggi 6,3 dan nilai terendah 3,7 (rentang nilai 0 - 10).

Tabel I

Perhitungan poin hasil belajar siswi Pra Siklus

\begin{tabular}{|l|l|c|}
\hline No. & \multicolumn{1}{|c|}{ Uraian } & Hasil PraSiklus \\
\hline 1. & $\begin{array}{l}\text { Nilai rata-rata tes } \\
\text { keterampilan passing }\end{array}$ & 56.40 \\
2. & $\begin{array}{l}\text { Jumlah siswi yang tuntas } \\
\text { belajar }\end{array}$ & 15 \\
3. & $\begin{array}{l}\text { Persentase ketuntasan } \\
\text { belajar }\end{array}$ & $50.00 \%$ \\
\hline
\end{tabular}

Pada pra-siklus diperoleh hasil bahwa keterampilan passing bawah bola voli siswi kelas IX-J MTsN 4 Jombang tidak tuntas(50\%). Hasil ini Jauh dari kriteria ketuntasan mininal $78 \%$ Siswi yang mendapat nilai di atas KKM hanya 15 siswi dari 30 siswi kelas IX-J MTsN 4 Jombang.

Pada siklus I diperoleh data pada tabel II Sebagai berikut:

Tabel II

Perhitungan poin hasil belajar dan ketuntasan belajar siswi siklus I

\begin{tabular}{|c|l|c|}
\hline No. & \multicolumn{1}{|c|}{ U ra ia n } & Hasil Siklus I \\
\hline 1. & $\begin{array}{l}\text { Nilai rata-rata tes } \\
\text { keterampilan passing }\end{array}$ & 76,70 \\
2. & $\begin{array}{l}\text { Jumlah siswi yang tuntas } \\
\text { belajar }\end{array}$ & 22 \\
3. & $\begin{array}{l}\text { Persentase ketuntasan } \\
\text { belajar }\end{array}$ & $73,33 \%$ \\
\hline
\end{tabular}

Pada siklus II diperoleh data pada tabel III sebagai berikut:

Tabel III

Perhitungan poin hasil belajar dan ketuntasan belajar siswi siklus ॥

\begin{tabular}{|c|l|c|}
\hline No. & \multicolumn{1}{|c|}{ Uraian } & Hasil Siklus II \\
\hline 1. & $\begin{array}{l}\text { Nilai rata-rata tes } \\
\text { keterampilan passing }\end{array}$ & 81,43 \\
2. & $\begin{array}{l}\text { Jumlah siswi yang tuntas } \\
\text { belajar }\end{array}$ & 26 \\
3. & $\begin{array}{l}\text { Persentase ketuntasan } \\
\text { belajar }\end{array}$ & $86,66 \%$ \\
\hline
\end{tabular}

Tabel IV

Perhitungan poin hasil belajar dan ketuntasan belajar siswi siklus III

\begin{tabular}{|l|l|c|}
\hline No. & \multicolumn{1}{|c|}{ Ur r i a n } & Hasil Siklus III \\
\hline 1. & $\begin{array}{l}\text { Nilai rata-rata tes } \\
\text { keterampilan passing }\end{array}$ & 87,43 \\
2. & $\begin{array}{l}\text { Jumlah siswi yang tuntas } \\
\text { belajar }\end{array}$ & 29 \\
3. & $\begin{array}{l}\text { Persentase ketuntasan } \\
\text { belajar }\end{array}$ & $96,66 \%$ \\
\hline
\end{tabular}

\section{B. Pembahasan}

Pada tabel I (Pra-siklus) KKM hanya $50 \%$. Jika kondisi ini dibiarkan maka tujuan pembelajaran keterampilan passing bawah bola voli peserta didik MTsN 4 Jombang tidak akan berhasil dengan baik.

\section{Siklus I :}

1. Perencanaan Tindakan (Planning)

Pada tahap perencanaan tindakan ini peneliti mempersiapkan perangkat pembelajaran yang terdiri dari Rencana Pelaksanaan Pembelajaran (RPP), buku pelajaran Penjas dan alat - alat yang dibutuhkan dalam permainan bola voli beserta netnya.

2. Pelaksanaan Tindakan (Action)

kegiatan siklus I dilaksanakan pada pada hari rabu tanggal 16 Oktober 2019 jam 08.00 sd 09.30 (jam 3 dan 4) di kelas IX-J dengan jumlah 30 siswi.

3. Observasi (Observation)

Pengamatan/ Observasi dilaksanakan bersama dengan pelaksanaan belajar mengajar. Pada akhir proses pembelajaran siswi diberi tes Ketrampilan passing bawah bola voli. Hasil tersebut masih banyak siswi yang belum tuntas hal ini disebabkan siswi masih merasa baru dan belum mengerti apa yang dimaksud dan digunakan guru dalam passing bola voli dengan menggunakan model pembelajaran Jigsaw.

4. Refleksi (Reflection)

Berdasarkan hasil yang didapat guru kurang baik dalam memotivasi siswi dalam menyampaikan tujuan pembelajaran sehingga siswa kurang begitu antusias selama pembelajaran berlangsung. 
Pada tabel II (Siklus I) diperoleh nilai ratarata prestasi belajar siswi adalah 76,70 dan ketuntasan belajar mencapai $73,33 \%$ atau dari 30 siswi ada 22 siswi yang sudah tuntas belajar. Hasil tersebut menunjukkan bahwa pada siklus pertama secara klasikal siswi belum tuntas belajar, karena siswi yang memperoleh nilai $\geq$ 76,70 hanya sebesar $73,33 \%$ lebih kecil dari persentase ketuntasan yang dikehendaki yaitu sebesar 90\%. Hal ini disebabkan karena siswi masih merasa baru dan belum mengerti apa yang dimaksudkan dan digunakan guru dalam passing bawah bola voli dengan menggunakan model jigsaw.

Dalam pelaksanaan kegiatan belajar mengajar diperoleh hasil refleksi sebagai berikut:

1. Guru kurang baik dalam memotivasi siswa dan dalam menyampaikan tujuan pembelajaran

2. Guru kurang baik dalam pengelolaan waktu

3. Siswi kurang begitu antusias selama pembelajaran berlangsung.

\section{Siklus II:}

1. Perencanaan Tindakan (Planning)

Pada tahap perencanaan tindakan ini penelitian mempersiapkan perangkat pembelajaran yang terdiri dari Rencana Pelaksanaan Pembelajaran (RPP), buku pelajaran Penjas dan alat - alat yang dibutuhkan dalam permainan bola voli beserta netnya.

2. Pelaksanaan Tindakan (Action)

kegiatan siklus II ini dilaksanakan pada pada hari rabu Tanggal 30 Oktober 2019 jam 08.00 sd 09.30 (jam 3 dan 4) di kelas IX-J dengan jumlah 30 siswi.

3. Observasi (Observation)

Berdasarkan hasil pengamatan (Observasi) pada siklus II ini kesalahan atau kekurangan pada siklus I di perbaiki sehingga menghasilkan peningkatan ketuntasan belajar bersama dengan pelaksanaan belajar mengajar. Pada akhir proses pembelajaran siswi diberi tes Ketrampilan passing bawah bola voli. Hasil tersebut masih ada beberapa siswi yang belum tuntas hal ini disebab kan siswi masih mengalami kesulitan dalam mengikuti pembelajaran diantaranya ada beberapa siswi masih merasa malu sehingga dalam melakukan passing bawah bola voli tidak sesuai apa yang diharapkan sama guru.

4. Refleksi (Reflection)

Pada tahap ini akan dikaji apa yang telah terlaksana dengan baik maupun yang kurang baik dalam proses belajar keterampilan passing bawah bola voli dengan model pembelajaran jigsaw.

Pada tabel III (siklus II) diperoleh nilai ratarata prestasi belajar siswi adalah 81,43 dan ketuntasan belajar mencapai $86,66 \%$ atau dari 30 siswi ada 26 siswi sudah tuntas belajar. Hasil ini menunjukkan bahwa pada siklus II ini ketuntasan belajar secara klasikal telah mengalami peningkatan sedikit lebih baik dari siklus I. Adanya peningkatan hasil belajar siswi ini karena setelah guru menginformasikan bahwa setiap akhir pelajaran akan selalu diadakan tes sehingga pada pertemuan berikutnya lebih termotivasi untuk belajar. Selain itu siswi juga sudah mulai mengerti apa yang dimaksudkan dan diinginkan guru dengan ketrampilan passing bawah pada bola voli Siklus 2 .

Dalam pelaksanaan kegiatan belajar siklus II diperoleh hasil refleksi sebagai berikut:

1. Masih ada beberapa siswi yang kurang ber semangat sehingga perlu diberi motivasi.

2. Masih ada siswi yang salah dalam melakukan passing bawah pada bola voli sehingga perlu bimbingan

3. Pengelolaan waktu perlu diperbaiki

\section{Siklus III:}

1. perencanaan Tindakan (Planning)

Pada tahap perencanaan tindakan ini penelitian mempersiapkan perangkat pembelajaran yang terdiri dari Rencana Pelaksanaan Pembelajaran (RPP), buku pelajaran Penjas dan alat-alat yang dibutuhkan dalam permainan bola voli beserta netnya.

2. Pelaksanaan Tindakan (Action)

kegiatan siklus III ini dilaksanakan pada hari rabu tanggal 13 Nopember 2019 jam 08.00 sd 09.30 (jam 3 dan 4) di kelas IX-J dengan jumlah 30 siswi.

3. Observasi (Observation)

Berdasarkan hasil pengamatan (Observasi) pada siklus III ini dilaksanakan bersama dengan pelaksanaan belajar mengajar. Pada akhir proses pembelajaran siswi diberi tes Ketrampilan 
passing bawah bola voli. Hasil pembelajaran dengan menggunakan model pembelajaran jigsaw terhadap penguasaan ketrampilan passing bawah bola voli tersebut sudah banyak siswi yang tuntas hal ini disebabkan siswi sudah mengerti apa yang dimaksud dan digunakan guru dalam passing bola voli dengan mengguna kan model pembelajaran Jigsaw.

4. Refleksi (Reflection)

Pada siklus III ini guru telah menerapkan model pembelajaran dengan baik dan dilihat dari aktifitas siswi serta hasil belajar siswi sudah berjalan dengan baik. Maka tidak perlu ada siklus berikutnya. Dengan demikian dapat di simpulkan bahwa model pembelajaran jigsaw terhadap penguasaan keterampilan passing bawah bola voli mendapat respon sangat baik dari peserta didik.

Hasil penelitian pada siklus III (tabel IV) diperoleh nilai rata-rata tes keterampilan passing bola voli sebesar 87,43 dan dari 30 siswi yang telah tuntas sebanyak 29 siswi dan 1 siswi belum mencapai ketuntasan belajar. Maka secara klasikal ketuntasan belajar yang telah tercapai sebesar 96,66 \% (termasuk kategori tuntas). Hasil pada siklus III ini mengalami peningkatan lebih baik dari siklus II. Adanya peningkatan hasil belajar pada siklus III ini dipengaruhi oleh adanya peningkatan kemampuan guru dalam menerapkan ketrampilan passing sehingga siswi menjadi lebih terbiasa dengan pembelajaran seperti ini sehingga siswi lebih mudah dalam memahami materi yang telah diberikan.

Pada akhir siklus III akan dikaji apa yang telah terlaksana dengan baik maupun yang masih kurang baik dalam proses belajar mengajar keterampilan bola voli dengan menggunakan model jigsaw. Dari data-data yang telah diperoleh dapat diuraikan sebagai berikut:

1. Selama proses belajar mengajar guru telah melaksanakan semua pembelajaran dengan baik. Meskipun ada beberapa aspek yang belum sempurna, tetapi persentase pelaksanaannya untuk masing-masing aspek cukup besar.

2. Berdasarkan data hasil pengamatan diketahui bahwa siswi aktif selama proses belajar berlangsung.

3. Kekurangan pada siklus-siklus sebelumnya sudah mengalami perbaikan dan peningkatan sehingga menjadi lebih baik.

Berdasarkan hasil observasi yang telah dilakukan, diperoleh aktivitas siswi dalam proses pembelajaran keterampilan passing bawah bola voli dengan model jigsaw bahwa semua siswi aktif melakukan passing tidak ada yang dudukduduk lagi, sedangkan untuk aktivitas guru selama pembelajaran telah melaksanakan langkah-langkah belajar aktif dengan baik. Hal ini terlihat dari aktivitas guru yang muncul diantaranya aktivitas membimbing dan mengamati siswi dalam melakukan kegiatan keterampilan passing bawah bola voli.

Melalui hasil peneilitian ini menunjukkan bahwa model pembelajaran jigsaw terhadap penguasaan keterampilan passing bawah bola voli memiliki dampak positif dalam meningkatkan prestasi belajar siswi. Hal ini dapat dilihat dari semakin mantapnya pemahaman siswi terhadap materi yang disampaikan guru (ketuntasan belajar meningkat dari siklus I, II, dan III) yaitu masingmasing 73,33 \%, 86,66\%, dan 96,66 \%. Pada siklus III ketuntasan belajar siswi secara klasikal telah tercapai.

\section{PENUTUP}

\section{A. Simpulan}

Dari hasil kegiatan pembelajaran yang telah dilakukan selama tiga siklus dan berdasarkan seluruh pembahasan serta analisis yang telah dilakukan dapat disimpulkan sebagai berikut:

1. Pembelajaran keterampilan passing bawah bola voli siswi kelas IX-J MTSN 4 Jombang dengan menggunakan model jigsaw dilakukan dengan menggunakan 3 siklus. Setiap siklus terdiri dari perencanaan, pelaksanaan, observasi dan refleksi.

2. Penerapan model jigsaw mempunyai pengaruh positif, yaitu dapat meningkatkan hasil belajar siswi yang ditunjukan dengan hasil keterampilan pasing bawah bola voli pada siswi dalam setiap siklus, yaitu siklus I $(73,33 \%)$, siklus II $(86,66 \%)$, siklus III $(96,66 \%)$. 


\section{B. Rekomendasi}

Dari hasil penelitian ini, maka disampaikan saran sebagai berikut:

1. Guru Penjaskes bisa melaksanakan pembelajaran keterampilan passing bawah bola voli dengan menggunakan model pembelajaran Jigsaw.
2. Pembelajaran keterampilan passing bawah bola voli dengan menggunakan model pembelajaran Jigsaw terbukti bisa meningkatkan hasil belajar peserta didik sehingga bisa ditiru oleh guru-guru Penjaskes yang lain. $[\alpha]$

\section{DAFTAR PUSTAKA}

Ahmadi Nuril. (2007). Panduan olahraga Bola Voli. Solo: Era Pustaka Utama.

Fathurrohman, Muhammad. (2015). Model-model Pembelajaran Inovatif. Yogyakarta: Ar- ruzz Media.

Hamdayama, J. (2014). Model dan Metode Pembelajaran Kreatif dan Berkarakter. Bogor: Ghalia Indonesia. Isjoni. (2013). Cooperative Learning. Bandung: Alfabeta.

Istarani. (2014). Model Pembelajaran Inovatif. Medan: Media Persada.

Kusumah, Wijaya dan Dedi Dwitagama. (2011) Penelitian Tindakan Kelas. Jakarta: PT Indeks

Majid, A. (2017). Strategi Pembelajaran. Bandung: PT. Remaja Rosdakarya.

Mashar, M. Ali dan Dwinarhayu. (2010). Pendidikan Jasmani Olahraga dan Kesehatan untuk Sekolah Menengah Pertama IX. Jakarta: Pusat Perbukuan Kementerian Pendidikan Nasional.

Matali, (2013). Penggunaan Model Pembelajaran Talking Stick Modifikasi Tanya Jawab dengan Media Jam Berputar untuk meningkatkan Hasil Belajar Mata Pelajaran IPS Pada Siswa Kelas VIII F MTsN Rogojampi Banyuwangi Semester Ganjil Tahun pelajaran 2012/ 2013. Inovasi Jurnal Diklat Keagamaan 7 (03), 340

M. Yunus. (1992). Olah Raga Pilihan Bola Voli. Jakarta: Depdikbud.

Rusman. (2018). Model - Model Pembelajaran: Mengembangkan Profesionalisme Guru. Jakarta: PT. Raja Grafindo Persada.

Sarjiyanto dan Sujarwadi. (2010). Pendidikan Jasmani Olahraga dan Kesehatan untuk Kelas VII SMP/ MTs. Jakarta: Pusat Perbukuan Kementerian Pendidikan Nasional.

Sarumpaet, A dkk. (1992). Permainan Bola Besar. Jakarta: Depdikbud. Dirjendikti. Proyek Pembinaan Tenaga Kependidikan.

Sholihah, Imroatus. (2020). Peningkatan Ketrampilan Berbicara Dalam Menanggapi Pembacaan Cerpen Melalui Model Pembelajaran Kepala Bernomor Struktur Pada Peserta Didik di MTsN 4 Jombang, Inovasi Jurnal Diklat Keagamaan, 14 (02). 151.

Syarifuddin Aip. (1991). Pengetahuan Olahraga. Jakarta: CV Baru

Suherti, Euis \& Rohimah, Siti Maryam. (2016). Bahan Ajar Mata Kuliah Pembelajaran Terpadu. Bandung: Universitas Pasundan.

Sugiarto. (2009). Langkah Menjadi Pemain Voli Hebat. Jakarta: PT Intan Sejati klaten.

Suharno, HP. (1993). IImu Kepelatihan Olahraga. Bandung. PT. Karya Ilmu.

Sukintaka dkk. (1979). Permainan dan Metodik. Buku I. Bandung: Depertement Pendidikan dan Kebudayaan. Yamin, Martinis. (2013). Strategi dan Metode dalam Model Pembelajaran. Jakarta: GP Press Grup. Vanalita, Mila, Jalmo T \& Marpaung. (2014). Pengaruh Pembelajaran Jigsaw terhadap Kemampuan Komunikasi Lisan dan Hasil Belajar Siswa. Jurnal Bioterdidik Vol 2, No 9. Bandar Lampung. (Universitas Lampung). 